\title{
Article
}

https://doi.org/10.11646/phytotaxa.371.1.4

\section{Zingela (Asparagaceae, Scilloideae), a distinct new urgineoid genus from KwaZulu-Natal, South Africa}

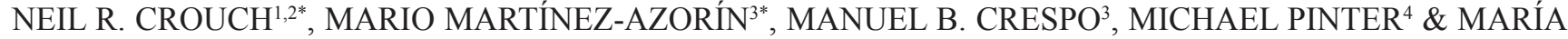 \\ Á. ALONSO-VARGAS ${ }^{3}$ \\ ${ }^{1}$ Biodiversity Research, Assessment \& Monitoring, South African National Biodiversity Institute, P.O. Box 52099, Berea Road 4007, \\ South Africa; e-mail: n.crouch@sanbi.org.za \\ ${ }^{2}$ School of Chemistry and Physics, University of KwaZulu-Natal, Durban 4041, South Africa \\ ${ }^{3} d$ CARN (Depto. Ciencias Ambientales y Recursos Naturales) and CIBIO (Instituto Universitario de la Biodiversidad), Universidad de \\ Alicante, P.O.Box 99,E-03080Alicante,Spain; e-mail:mmartinez@ua.es \\ ${ }^{4}$ Institute of Biology, Division Plant Sciences, NAWI Graz, Karl-Franzens-University Graz, Holteigasse 6, A-8010, Graz, Austria \\ *authors for correspondence
}

\begin{abstract}
In the course of resolving the identity of plants usually named 'Drimia indica' from KwaZulu-Natal Province, South Africa, molecular and morphological data revealed the identity of more than one taxon carrying this name. Our studies support the establishment of a new urgineoid genus, Zingela gen. nov., to accommodate a species (Z. pooleyorum) collected and illustrated some 50 years ago, but never validly published. We here provide data on its morphology, ecology, and distribution.
\end{abstract}

Keywords: Drimia, Hyacinthaceae, taxonomy, Urgineoideae, Zingela

\section{Introduction}

Hyacinthaceae sensu APG (2003) includes ca. 700-1000 species of bulbous plants mostly occurring in Africa, Europe, and Asia, with a single genus, Oziroe Rafinesque (1837: 53), in South America (Speta 1998a, b, APG 2003, MartínezAzorín et al. 2011). Four subfamilies are accepted in Hyacinthaceae (Hyacinthoideae, Ornithogaloideae, Oziroëoideae and Urgineoideae), corresponding to monophyletic clades (Speta 1998b, Pfosser \& Speta 1999, Manning et al. 2004, Martínez-Azorín et al. 2011). Alternatively, Hyacinthaceae is treated as Asparagaceae subfamily Scilloideae, and consequently the former subfamilies are reduced respectively to the tribes Hyacintheae, Ornithogaleae, Oziroëeae, and Urgineeae (APG 2016, Chase et al. 2009).

Generic circumscriptions within Urgineoideae have been especially controversial in recent decades. This subfamily occurs in Africa, Europe, and western Asia, reaching Indochina in the east. Although some studies accept only ca. 100 species in Urgineoideae (Manning et al. 2004), we consider the true number to be considerably greater, given the imperfect knowledge of urgineoids across their wide distribution range, and the lack of detailed comprehensive taxonomic revisions. The paucity of good revisions has precluded improved generic circumscriptions and so widely differing taxonomies have been proposed. On the one hand, Manning et al. (2004) presented, based on disputable phylogenetic data, a very broad-concept treatment, where only two genera were recognised for the whole subfamily: Bowiea Harvey ex Hooker (1867: t. 5619) with two species (Reid et al. 1990), and Drimia Jacquin (1797: 38) with about 100 species involved. This study expanded the concept of Drimia to accommodate enormous variation in floral and vegetative morphologies, and resulted in the synonymisation of several traditionally accepted genera which are easily identified by distinct morphological syndromes. The synonymised genera include Litanthus Harvey (1844: 314), Rhadamanthus Salisbury (1866: 37), Rhodocodon Baker (1880: 280), Schizobasis Baker (1873: 105), Tenicroa Rafinesque (1837: 52), Thuranthos Wright (1916: 233), and Urginea Steinheil (1834: 321). On the other hand, Speta (1998a, 1998b, 2001) and Pfosser \& Speta (2001) favoured a more analytical approach, in which about 20 different genera (excluding Igidia Speta (1998b: 70) of subfamily Ornithogaloideae, see Wetschnig et al. 2007), were accepted. However, some of these genera were found to be para- or polyphyletic (Pfosser \& Speta 2001, 2004, Manning et al. 2004, Pfosser et al. 2012). 
Generic delimitations in Urgineoideae supported by morphological synapomorphies and molecular data are becoming increasingly well-defined. Our phylogenetic studies in the subfamily (M. Martínez-Azorín and collaborators, in preparation) include three plastidial regions $(\operatorname{trn} \mathrm{L}-\operatorname{trn} \mathrm{F}, \operatorname{mat} \mathrm{K}$ and ycf) and a nuclear one (Agt1) and more than 250 samples covering almost the entire subfamily distribution range. Our findings strongly support a multi-generic treatment in Urgineoideae, with taxa arranged in several well-supported clades that correspond to distinct traditionally accepted genera, and/or clades which show unique syndromes of morphological characters and biogeography. This molecular work has motivated the circumscription of some recently described genera such as Mucinaea M.Pinter, Mart.-Azorín, U.Müll.-Doblies, D.Müll.-Doblies, Pfosser \& Wetschnig in Pinter et al. (2013: 296), Sagittanthera Mart.-Azorín, M.B.Crespo, A.P.Dold \& van Jaarsv. in Martínez-Azorín et al. (2013b: 46), Aulostemon Martínez-Azorín et al. (2017: 288) and Austronea Mart.-Azorín, M.B.Crespo, M.Pinter \& Wetschnig in Martínez-Azorín et. al. (2018: 105) besides Iosanthus Martínez-Azorín et al. (2018: in press). This taxonomic treatment for Urgineoideae parallels that presented for the sister subfamily Ornithogaloideae (Martínez-Azorín et al. 2011), in which consistent morphological elements recognised at generic rank are fully congruent with clades based on plastidial and nuclear DNA regions.

The taxonomic subject of this paper was first observed and collected approximately 50 years ago by Elsa Pooley in the Ndumo Game Reserve (GR) in Maputaland, northern KwaZulu-Natal (Pooley 661, NU). Elsa Pooley also illustrated this taxon at the time of collection (Fig. 1). We were able to collect this same species in Ndumo GR as well as to the south along the mid-reaches of the Thukela River (Fig. 1). Our studies revealed that these plants show a unique syndrome of morphological characters within the Urgineoideae.

To obtain a name Pooley sent her voucher (Pooley 661, NU) to O. Hilliard at NU for identification, through which repository it was forwarded to A.A. Mauve (Obermeyer) at the National Herbarium of South Africa (PRE). Simultaneously, a specimen of a further urgineoid was gathered in Ndumo GR (Pooley 127, NU), which the collector recognised as different in several respects, most notably in leaf and bulb form, in the number, size and orientation of flowers, in floral scent and opening times, and in habitat preference (Pooley 1978). This taxon was also illustrated by E. Pooley (Fig. 1). Recent observations of this species in Ndumo GR and in cultivation have revealed several significant features that distinguish it from Pooley 661 (NU). The bulb is compact; leaves synanthous, narrowly canaliculated, with dark green maculations below that merge to form distinct transverse bands along the entire length, especially at the base; lax raceme with up to 13 flowers, pedicels $20-30 \mathrm{~mm}$ long; bracts minute and inconspicuous at anthesis; bracteoles absent; flowers brown, nodding, nocturnal, strongly scented; stamens curved; filaments free, incurved along the lower half, almost connivent to style in middle section and spreading distally, thickened, terete in cross-section, proximally attenuated to only $0.3 \mathrm{~mm}$ wide; anthers not circinnate; ovary ovate with narrowly clavate, deflexed style and subcapitate stigma; and capsule ovate with conspicuous chestnut markings.

Our study revealed that the collections Pooley 127 and Pooley 661 held at NU not only belong to two different species, but to two different genera within the Urgineoideae, based on clear morphological differences and conspicuous genetic divergence. Preliminary molecular analyses reveal that plants with hysteranthous, keeled leaves, multiflowered racemes, diurnal flowers and spreading stamens with circinnate anthers (corresponding to Pooley 661, NU) are placed in an isolated position within our Urgineoideae phylogeny. These represent a distinct genus, here named Zingela. Four samples of Zingela from the KwaZulu-Natal Province form a well-supported clade in our phylogeny which is sister to Thuranthos s.str., represented in South Africa by T. macranthum Wright (1916: 223), T. nocturnale Dyer (1964: t. 1439), and T. basuticum (Phillips 1917: 306) Obermeyer (1980: 139) which also forms a strongly supported clade. However, the clade comprising both Zingela and Thuranthos show weak bootstrap support, hindering inclusion of Zingela in Thuranthos. Further, Thuranthos differs morphologically from Zingela in having the filaments of the stamens distinctly broad in the lower half and constricted at their middle to form a cage-like structure connivent to the style; nocturnal flowers with a distinct musty scent; flower bracts early caducous, and leaves that are immaculate. On the other hand, Pooley 127 (NU) resolved in a well-supported clade together with Vera-duthiea Speta (2016: 154) sampled from central Africa, a finding supported by floral morphology comparison. This latter collection will be published soon as V. zebrina Mart.-Azorín et al. (in prep.) (Fig. 1C).

Nonetheless, the affinities of these two taxa originally collected by Pooley in Ndumo GR were related by Obermeyer in 1970 to Urginea indica (Roxburgh 1832: 147) Kunth (1843: 333). However, as reflected in her correspondence and also sheet annotations, Obermeyer initially considered both taxa to be new, with Pooley 661 (NU) only a floriferous variety of Pooley 127 (NU). She accordingly proposed the names in scheda "Urginea zebrina Oberm. n. sp. ms." for Pooley 127 (NU) and "Urginea zebrina Oberm. n. sp. var. multiflora Oberm. var. nov. ms." for Pooley 661 (NU). Shortly thereafter, and seemingly based on the opinion of the South African Botanical Liaison Officer (SABLO) at Kew (then D. Killick), Obermeyer accepted both taxa to be conspecific with the 'variable' U. indica, a view reflected thereafter in Hyacinthaceae treatments for the FSA region (e.g., Jessop 1977 who treated Drimia indica (Roxburgh 
1832: 147) Jessop 1977: 272). Based on new evidence, and given that neither of the in scheda names have been validly published, we here recognise Pooley 661 (NU) at a different rank and describe Zingela pooleyorum, which also represents and typifies a new urgineoid genus.

Notably, our phylogenetic studies include several samples of Drimia indica from India and Thailand and these form a well-supported monophyletic clade which corresponds to Indurgia Speta (2001: 169), a genus putatively endemic to southwestern Asia. Further, the Indurgia clade is far placed from the Zingela, Thuranthos and Vera-duthiea clades. Although some species of Indurgia are superficially similar, in vegetative or sexual form, to species of Zingela and Vera-duthiea - probably due to convergence events and at times nocturnal flowering patterns - the Asian taxa are morphologically distinct from both of the South African taxa collected by Pooley. We, therefore, exclude Drimia indica from the South African plant species catalogue.
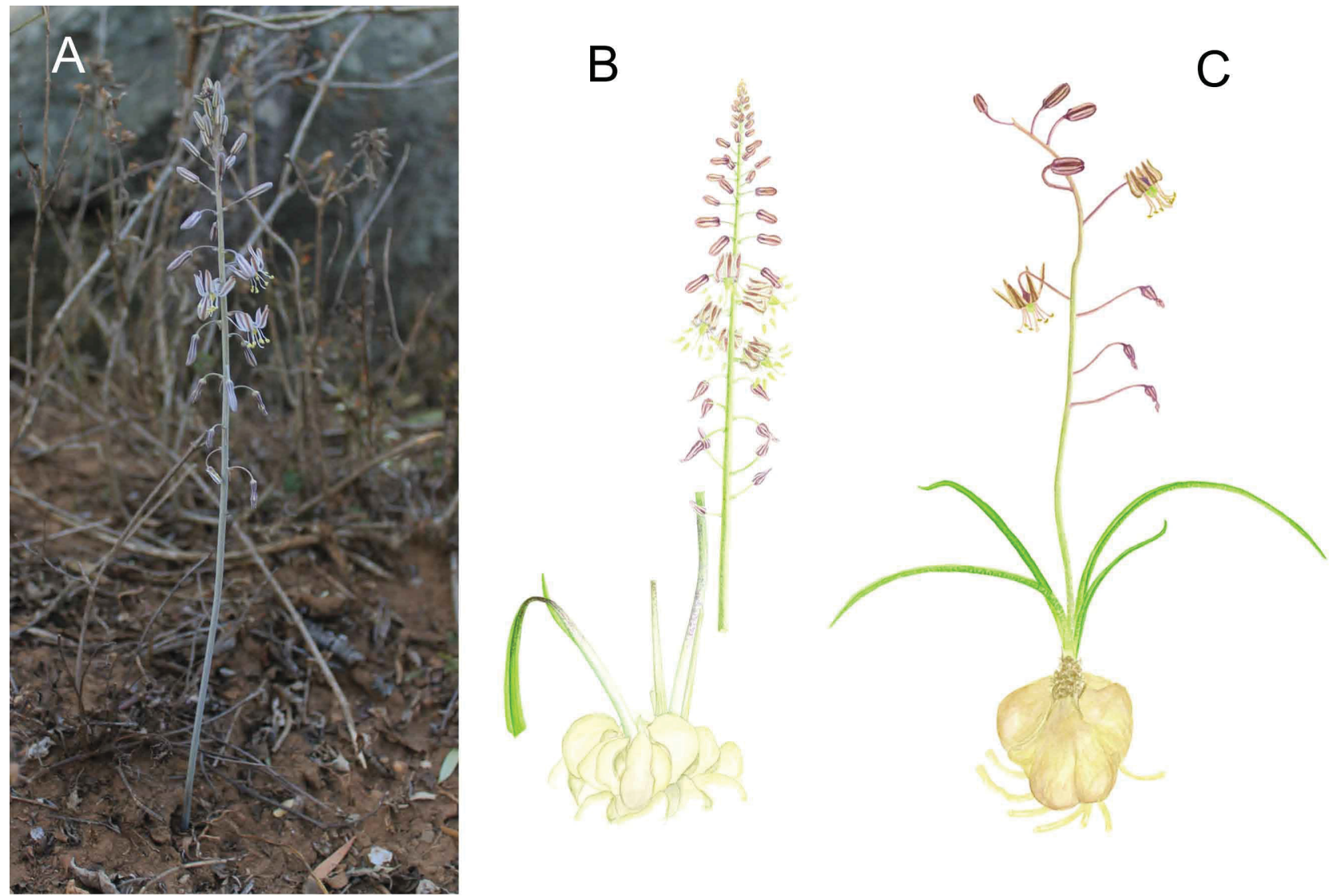

FIGURE 1. A. Zingela pooleyorum N.R.Crouch, Mart.-Azorín, M.B.Crespo, M.Pinter \& M.A.Alonso plant in flower at Zingela, E of Colenso, KwaZulu Natal Province, South Africa, on 11 October 2015; B Zingela pooleyorum; C. Vera-duthiea, both from Ndumo Game Reserve, KwaZulu-Natal Province, South Africa, corresponding to Pooley 661 (NU) and Pooley 127 (NU) respectively.

\section{Materials and methods}

Detailed morphological studies of Zingela pooleyorum and related taxa from South Africa were undertaken on natural populations as elaborated upon in Martínez-Azorín et al. (2007, 2009). Herbarium specimens from the following herbaria were studied: ABH, BOL, GRA, NBG, NH, NU, and PRE (acronyms according to Thiers 2018). Nomenclatural issues accord with the Shenzhen Code (Turland et al. 2018). 


\section{Description of the new genus}

\section{Zingela N.R.Crouch, Mart.-Azorín, M.B.Crespo, M.Pinter \& M.A.Alonso gen. nov. (Fig. 2)}

The new genus differs from Thuranthos in its staminal filaments which spread rather than constrict at the middle to form a cage-like structure connivent to the style, and are essentially filiform rather than distinctly broad in the lower half. Although both genera are hysteranthous the flowers of Zingela are diurnal rather than nocturnal as with Thuranthos, and lack the distinct musty scent characteristic of the latter. The flower bracts of Zingela persist at flowering whereas those of Thuranthos are early caducous. The leaf bases of Zingela additionally exhibit obvious purple maculations, a feature not documented for Thuranthos.

Type:-Zingela pooleyorum N.R.Crouch, Mart.-Azorín, M.B.Crespo, M.Pinter \& M.A.Alonso (holotype).

Etymology:-Zingela: after the location in central KwaZulu-Natal where the authors first encountered plants of this genus in flower.

Zingela pooleyorum N.R.Crouch, Mart.-Azorín, M.B.Crespo, M.Pinter \& M.A.Alonso sp. nov. (Figs. 1A-B, 2, 3).

$=$ Urginea indica (Roxb.) Kunth var. multiflora Oberm. nom. nud. (Art. 38 Ex. 1)

= Urginea zebrina Oberm. var. multiflora Oberm. nom. nud. in scheda

The new species shows a unique syndrome of characters, comprising loose-scaled bulbs; glaucous, hysteranthous, keeled leaves, bearing purple maculations at the base; long multiflowered racemose inflorescence with persistent bracts and distinct bracteoles; subpatent to nodding, faintly scented diurnal flowers, with almost free, white, reflexed tepals; spreading stamens with filiform filaments and circinnate anthers post pollen release; ovary ovoid to subconical, style filiform, erect to slightly sinuous; and wide, shortly oblong capsules, differing from any other known Urgineoideae.

Type:-SOUTH AFRICA. KwaZulu-Natal, Bela Vista (2632CD): On Pongola floodplain edge, Ndumo [Ndumu] Hill, Ndumo [Ndumu] Game Reserve, 15 October 1969, E.S. Pooley 661 (holotype, NU!).

Herbaceous, perennial, bulbous plant. Bulb hypogeal, 5-8 × 6-9 cm, composed of 10-25 thickened, fleshy, white, elongated loose scales, with copious threads when torn, ca. $6 \times 1 \mathrm{~cm}$; roots pale brown, thickened, contractile, 2-5 $\mathrm{mm}$ in diameter. Leaves $1-2$, mostly hysteranthous, glaucous green, long narrowly oblong with pointed apex, 10-35 $\times 0.5-1 \mathrm{~cm}$, with 2 grooves adaxially, strongly keeled abaxially in a $\mathrm{V}$ shape, with the keel more prominent along the central part, commonly twisting from the base, sometimes distally, convolute at base with distinct purple maculations abaxially. Inflorescence long racemose, the peduncle 30-60 cm long, greenish-brown, mottled covered a white bloom, the raceme long and lax, 15-30 cm long, with 25-55 flowers, subpatent to nodding; pedicels of flowers 10-12 mm long, patent and arching down, purple-brown, with whitish bloom, elongating up to $2 \mathrm{~cm}$ long and arching up in fruit. Bracts lanceolate, acute, 2-4 mm long, cream with a brown central band, the lowermost with a long basal spur up to 6-8 mm long which is flattened and appressed to the stem, those from the middle and upper parts of the inflorescence showing very short or inconspicuous spurs, persistent at anthesis; bracteoles present and distinct, white. Flowers pentacyclic, trimerous, stellate, subpatent to nodding, opening in the afternoon and closing about sunset. Tepals 6 , biseriate, almost free from the base, reflexed, outer tepals lanceolate, 10-11 $\times 2.5-2.8 \mathrm{~mm}$, with obtuse apex, inner tepals oblong-lanceolate, 9-10 $\times 2.8-3 \mathrm{~mm}$, with acute apex; tepals white with a broad purplish-brown median stripe, being more evident abaxially. Stamens 6, spreading; filaments free, filiform, ca. $6 \times 0.3 \mathrm{~mm}$, only slightly flattened and triangular at the very base in connection to the ovary; anthers narrowly oblong, pale yellow, ca. $4 \times 0.8 \mathrm{~mm}$ before dehiscence, ca. $3 \mathrm{~mm}$ long and distinctly circinnate after pollen release, dehiscing longitudinally along the whole length, not connivent to the style. Ovary ovoid to subconical, yellowish, shallowly 3-angled, 3.8-4 mm long, $2.1 \mathrm{~mm}$ wide at the base and tapering to the style. Style filiform, white, erect to slightly sinuous, 5-5.7 $\times 0.4-0.5 \mathrm{~mm}$, curved outwards in the distal part. Stigma small and indistinctly trigonous. Capsule pale brown, triloculate, loculicide, shortly oblong, ca. $16 \times 13 \mathrm{~mm}$, valves splitting to the base. Seeds flattened, subelliptic, with prominent central embryo and broad wings, 10-11 $\times$ 5-7 mm, black, with puzzle-like cells delimited by narrow raised ridges (Figs. 1A-B, 2, 3).

Variation:-Plants from the Maputaland subpopulation present substantially broader median tepal stripes both above and below. In Ndumo GR, plants of $Z$. pooleyorum are generally larger, more erect, with longer leaves and inflorescences, and with anthers less strongly circinnate. 


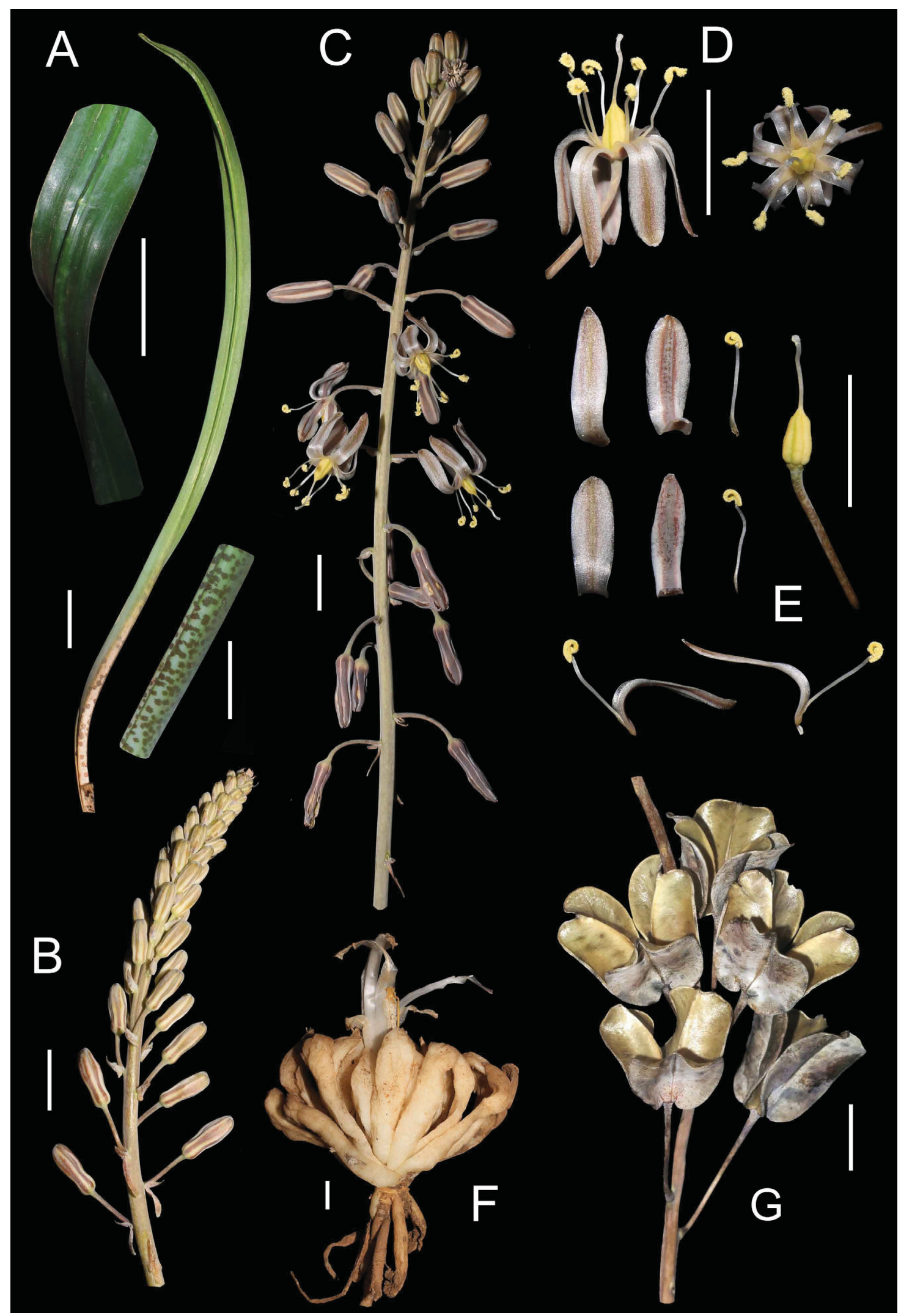

FIGURE 2. Zingela pooleyorum N.R.Crouch, Mart.-Azorín, M.B.Crespo, M.Pinter \& M.A.Alonso from Zingela, east of Colenso, KwaZulu-Natal Province, South Africa, on 11 October 2015, corresponding to MMA1382 (ABH74185). A. Leaves; B. Inflorescence in bud; C. Inflorescence at anthesis; D. Flowers, lateral and frontal views; E. Dissected flower; F. Bulb; G. Infructescence. Scale bars: 1 $\mathrm{cm}$. 



FIGURE 3. A-D. Seed morphology of Zingela pooleyorum N.R.Crouch, Mart.-Azorín, M.B.Crespo, M.Pinter \& M.A.Alonso from Crouch 1291 (ABH78366). Scale bars: A-B: $1 \mathrm{~mm}$; C: $100 \mu \mathrm{m}$; D: $10 \mu \mathrm{m}$.

Biology:-Flowering occurs in late spring and early summer, October through November in southern Africa, with the inflorescences fully developed even prior to the first seasonal rains. Both individuals in flower lacking leaves and in vegetative stage were simultaneously observed in the northernmost populations. The developing scapes are capable of penetrating remarkably compact dry soil, emerging from bulbs positioned up to $20 \mathrm{~cm}$ below the surface. The flowers open from $13 \mathrm{~h} 30$ until $18 \mathrm{~h} 00$, and are only faintly scented. Pollinators are not yet confirmed although Apis mellifera has been observed as a flower visitor.

Habitat:-At Ndumo Game Reserve plants grow in the partial shade of thicket at an elevation of approximately $50 \mathrm{~m}$, on both clay and sandy soils in both Western Maputaland Sandy Bushveld (SV1 19) and Western Maputaland Clay Bushveld (SVl 20) within the Savanna Biome (Rutherford et al. 2006). The Zingela subpopulation on the central Thukela River to the south occupies more stony terrain at elevations of 700-840 m, also within the Savanna Biome (Rutherford et al. 2006), but in Thukela Valley Bushveld (SVs 1). Pooley (1978) records that both leaves and flowering heads are eaten by duiker (antelope belonging to several genera of the family Bovidae, subfamily Cephalopinae).

Distribution:-Known so far only from two macrolocalities, some $300 \mathrm{~km}$ distant, both within the KwaZuluNatal Province, South Africa (Fig. 4). The likelihood of Z. pooleyorum occurring in southern Mozambique is very high given that the northern boundary of Ndumo GR forms part of the international border between these two countries. In correspondence (Ref 12/1/1/1, PRE) between A. Mauve and E. Pooley dated 3 April 1981, Mauve indicated that bulbs of Zingela had been found along the Sabie River near Skukuza in Kruger National Park, Mpumalanga. This locality requires confirmation.

Taxonomic relationships:-The alliance of Zingela is undoubtedly with Thuranthos which also has bulbs composed of loose, cucullate, pedicellate scales, and leaves which are prominently keeled. It is possible that Thuranthos macranthus Wright (1916: 223) is sympatric in the south of its range, although this has not been documented yet. The relationship to taxa in the Drimia indica complex (as Urginea indica) has been noted by A.A. Obermeyer in correspondence, when she considered attributing plants from Ndumo represented by Pooley 661 (NU) to the taxon "Urginea zebrina Oberm. var. multiflora Oberm.", through a name she annotated on that particular specimen. Her concept for ' $U$. zebrina' was never validly published, although the varietal epithet (as Urginea indica (Roxb.) Kunth var. multiflora Oberm.) was used in the checklist for the Ndumo Game Reserve (Pooley 1978), this being a nomen 
nudum (Art. 38 Ex. 1). Plants corresponding to the type of Drimia indica are not with certainty known from the African continent. Rather, our preliminary molecular findings reveal that the southern African material attributed to $D$. indica must be placed in Vera-duthiea.

Eponymy:- The name "pooleyorum" commemorates the award-winning conservationists Elsa Pooley (1947-) and Tony Pooley (1938-2004), whose manifold interest in the biota of Ndumo Game Reserve is reflected in Elsa's discovery of this species.

Additional material studied (paratypes):-SOUTH AFRICA. KwaZulu-Natal: Dundee (2830): ca. 24 km east of Colenso, on way to Zingela, ca. $2 \mathrm{~km}$ from main house (-CA), elev. $749 \mathrm{~m}, 11$ October 2015 (in flower), M. MartínezAzorin, M. Pinter, M.B. Crespo, N. Crouch \& M.A. Alonso MMA1382 (ABH74185!, GRA); Dundee (2830): ca. 24 km east of Colenso, on way to Zingela, ca. $4 \mathrm{~km}$ from main house (-CA), elev. $771 \mathrm{~m}, 12$ October 2015 (in flower), $M$. Martinez-Azorín, M. Pinter, M.B. Crespo, N. Crouch \& M.A. Alonso MMA1387 (ABH74190!, GRA); Immediately S of Ndumo Game Reserve, $0.8 \mathrm{Km}$ west of main gate to reserve (-CD), elev. 58 m, 16 November 2016, N. Crouch 1291 (ABH78366!).



FIGURE 4. Known distribution of Zingela pooleyorum N.R.Crouch, Mart.-Azorín, M.B.Crespo, M.Pinter \& M.A.Alonso in eastern South Africa.

\section{Acknowledgements}

This work was partly supported by H2020 Research and Innovation Staff Exchange Programme of the European Commission, project 645636: 'Insect-plant relationships: insights into biodiversity and new applications' (FlyHigh) and the complementary supporting funds UAUSTI17-03 and ACIE17-01 (University of Alicante, Spain). We thank the curators of the herbaria cited in the text for access to specimens, Ezemvelo-KZN Wildlife for a collecting permit (No. OP 3969/2015), Mark and Linda Caldwell of Zingela Safaris for facilitating access to their property, and to Mike Hickman for sharing his experiences of Zingela in Maputaland. Elsa Pooley provided copies of archival correspondence and kindly allowed reproduction of her previously unpublished watercolour plates of Zingela and Vera-duthiea, both of which were painted whilst she was based at Ndumo GR. 


\section{References}

APG (2003) An update of the Angiosperm Phylogeny Group classification for the orders and families of flowering plants: APG II. Botanical Journal of the Linnean Society 141: 399-436. https://doi.org/10.1046/j.1095-8339.2003.t01-1-00158.x

APG (2016) An update of the Angiosperm Phylogeny Group Classification for the orders and families of flowering plants: APG IV. Botanical Journal of the Linnean Society 181: 1-20.

https://doi.org/10.1111/boj.12385

Baker, J.G. (1873) On Schizobasis, a new genus of Liliaceae from Cape Colony. Journal of Botany, British and Foreign 11: 105.

Baker, J.G. (1880) Notes on a collection of flowering plants made by L. Kitching, Esq., in Madagascar in 1879. Journal of the Linnean Society, Botany 18: 264-281. https://doi.org/10.1111/j.1095-8339.1881.tb01257.x

Chase, M.W., Reveal, J.L. \& Fay, M.F. (2009) A subfamilial classification for the expanded asparagalean families, Amaryllidaceae, Asparagaceae and Xanthorrhoeaceae. Botanical Journal of the Linnean Society 161: 132-136. https://doi.org/10.1111/j.1095-8339.2009.00999.x

Dyer, R.A. (1964) Thuranthos nocturnale. Flowering plants of Africa 36: t. 1439.

Harvey, W.H. (1844) Litanthus, a new genus of Asphodeleae from South Africa. The London Journal of Botany 3: 314-315.

Hooker f., J.D. (1867) Bowiea volubilis. Curtis's Botanical Magazine Ser. 3, 23: t. 5619.

Jacquin, N.J. (1797) Observationes botanicae DXIX-DCLXXI. Collectaneorum Supplementum vol. 5. Vindobonae, Ex Officina Wappleriana, $171 \mathrm{pp}, 16 \mathrm{t}$.

Jessop, J.P. (1977) Studies in the bulbous Liliaceae in South Africa 7. The Taxonomy of Drimia and certain allied genera. Journal of South African Botany 43: 265-319.

Kunth, K.S. (1843) Enumeratio plantarum omnium hucusque cognitarum, secundum familias naturales disposita, adjectis characteribus, differentiis et synonymis 4. J.G. Cottae, Stutgardiae et Tubingae, $752 \mathrm{pp}$.

Manning, J.C., Goldblatt, P. \& Fay, M.F. (2004) A revised generic synopsis of Hyacinthaceae in Sub-Saharan Africa, based on molecular evidence, including new combinations and the new tribe Pseudoprospereae. Edinburgh Journal of Botany 60: 533-568.

Martínez-Azorín, M., Crespo, M.B., Alonso-Vargas, M.Á., Dold, A.P., Pinter, M. \& Wetschnig, W. (2018) Austronea (Asparagaceae, Scilloideae), a new genus from southern Africa, including the description of seven new species. Phytotaxa 365: 101-129. https://doi.org/10.11646/phytotaxa.365.2.1

Martínez-Azorín, M., Crespo, M.B., Dold, A.P., Wetschnig, W., Pinter, M., Pfosser, M. \& Van Jaarsveld, E. (2013) Sagittanthera (Hyacinthaceae, Urgineoideae), a new buzz pollinated genus from the Eastern Cape Province of South Africa. Phytotaxa 98: 43-54. https://doi.org/10.11646/phytotaxa.98.2.2

Martínez-Azorín, M., Crespo, M.B. \& Juan, A. (2007) Taxonomic revision of Ornithogalum subg. Cathissa (Salisb.) Baker (Hyacinthaceae). Anales del Jardín Botánico de Madrid 64: 7-25. https://doi.org/10.3989/ajbm.2007.v64.i1.47

Martínez-Azorín, M., Crespo, M.B. \& Juan, A. (2009) Taxonomic revision of Ornithogalum subg. Beryllis (Hyacinthaceae) in the Iberian Peninsula and the Balearic Islands. Belgian Journal of Botany 142: 140-162.

Martínez-Azorín, M., Crespo, M.B., Juan, A. \& Fay, M.F. (2011) Molecular phylogenetics of subfamily Ornithogaloideae (Hyacinthaceae) based on nuclear and plastid DNA regions, including a new taxonomic arrangement. Annals of Botany 107: 1-37. https://doi.org/10.1093/aob/mcq207

Martínez-Azorín, M., Crespo, M.B., Pinter, M. \& Wetschnig, W. (2017) Aulostemon (Asparagaceae, Scilloideae), a new genus from South Africa. Phytotaxa 321: 287-293.

https://doi.org/10.11646/phytotaxa.321.3.6

Martínez-Azorín, M. Crespo, M.B., Pinter, M., Slade, J.M. \& Wetschnig, W. (2018) Iosanthus (Hyacinthaceae subfam. Urgineoideae), a new genus from southern Africa to include Ornithogalum toxicarium and its removal from Ornithogaloideae. Plant Biosystems: in press.

Obermeyer, A.A. (1980) A new combination in Thuranthos. Bothalia 13: 139.

Phillips, E.P. (1917) A contribution to the flora of the Leribe plateau and environs, with a discussion on the relationships of the floras of Basutoland, the Kalahari and the south-eastern regions. Annals of South African Museum 16: 1-372.

Pinter, M., Crespo, M.B., Ilg, I., Luidold, A.K., Martínez-Azorín, M., Müller-Doblies, U., Müller-Doblies, D., Pfosser, M. \& Wetschnig, W. (2013) Mucinaea (Hyacinthaceae-Urgineoideae), a remarkable new genus from Namaqualand (Northern Cape Province, South Africa). Phyton 53: 289-304. 
Pfosser, M. \& Speta, F. (1999) Phylogenetics of Hyacinthaceae based on plastid DNA sequences. Annals of the Missouri Botanical Garden 86: 852-875.

https://doi.org/10.2307/2666172

Pfosser, M. \& Speta, F. (2001) Bufadienolides and DNA sequences: on lumping and smashing of subfamily Urgineoideae (Hyacinthaceae). Stapfia 75: 177-250.

Pfosser, M. \& Speta, F. (2004) From Scilla to Charybdis - is our voyage safer now? Plant Systematics and Evolution 246: $245-263$.

Pfosser, M., Knirsch, W., Pinter, M., Ali, S., Dutta, S. \& Wetschnig, W. (2012) Phylogenetic relationships of Malagasy Hyacinthaceae. Plant Ecology and Evolution 145: 65-72. https://doi.org/10.5091/plecevo.2012.590

Pooley, E.S. (1978) Checklist of the flora of Ndumu Game Reserve, north-eastern Zululand. Journal of South African Botany $44:$ 1-54. Rafinesque, C.S. (1837) Flora Telluriana 3. H. Probasco, Philadelphia, PA, 100 pp.

Reid, C., Müller-Doblies, D. \& Müller-Doblies, U. (1990) Bowiea gariepensis; southern Namibia and northern Cape; Liliaceae/ Hyacinthaceae. Flowering Plants of Africa 51: t. 2007.

Roxburgh, W. (1832) Flora Indica 2. Thacker \& co., Calcutta, 691 pp.

Rutherford, M.C., Mucina, L., Lötter, M.C., Bredenkamp, G.J., Smit, J.H.L., Scott-Shaw, C.R.,Hoare, D.B., Goodman, P.S., Bezuidenhout, H., Scott, L., Ellis, F., Powrie, L.W., Siebert, F., Mostert, T.H., Henning, B.J., Venter, C.E., Camp, K.G.T., Siebert, S.J., Matthews, W.S., Burrows, J.E., Dobson, L., Van Rooyen, N., Schmidt, E., Winter, P.J.D., Du Preez, P.J., Ward, R.A., Williamson, S.\& Hurter, P.J.H. (2006) Savanna Biome. In: Mucina, L. \& Rutherford, M.C. (Eds.) The vegetation of South Africa, Lesotho and Swaziland. Strelitzia 19. pp. 439-567.

Salisbury, R.A. (1866) The genera of plants: a fragment containing part of Liriogamae. John van Voorst, London, 143 pp.

Speta, F. (1998a) Hyacinthaceae. In: Kubitzki, K. (Ed.) The families and genera of vascular plants 3. Springer, Berlin, pp. 261-285. https://doi.org/10.1007/978-3-662-03533-7_35

Speta, F. (1998b) Systematische Analyse der Gattung Scilla L. s.l. (Hyacinthaceae). Phyton (Horn) 38: 1-141.

Speta, F. (2001) Die echte und die falsche Meerzwiebel: Charybdis Speta und Stellarioides Medicus (Hyacinthaceae), mit Neubeschreibungen und Neukombinationen im Anhang. Stapfia 75: 139-176.

Speta, F. (2016) Substitution of an illegitimate generic name in Hyacinthaceae, and validation of names of already described species in Ornithogalum (Hyacinthaceae) and Pinguicula (Lentibulariaceae). Phyton (Horn) 56: 153-159.

Steinheil, A. (1834) Note sur le genre Urginea nouvellement formé dans la famille des Liliacées. Annales des Sciences Naturelles, Botanique sér. 2 1: 321-332.

Thiers, B. (2018) Index Herbariorum: A global directory of public herbaria and associated staff. New York Botanical Garden's Virtual Herbarium. Available from: http://sweetgum.nybg.org/ih/ (accessed 15 June 2018)

Turland, N.J., Wiersema, J.H., Barrie, F.R., Greuter, W., Hawksworth, D.L., Herendeen, P.S., Knapp, S., Kusber, W.-H., Li, D.-Z., Marhold, K., May, T.W., McNeill, J., Monro, A.M., Prado, J., Price, M.J. \& Smith, G.F. (Eds.) (2018) International Code of Nomenclature for algae, fungi, and plants (Shenzhen Code) adopted by the Nineteenth International Botanical Congress Shenzhen, China, July 2017. Koeltz Scientific Books, Königstein, 254 pp.

Wetschnig, W., Knirsch, W., Ali, S.S. \& Pfosser, M. (2007) Systematic position of three little known and frequently misplaced species of Hyacinthaceae from Madagascar. Phyton (Horn) 47: 321-337.

Wright, C.H. (1916) Diagnoses africanae: LXIX. Bulletin of Miscellaneous Information, Royal Botanic Gardens, Kew 1916: $229-235$. https://doi.org/10.2307/4114331 